\title{
Mitotic Catastrophe Induced in HeLa Tumor Cells by Photodynamic Therapy with Methyl-aminolevulinate
}

\author{
Marta Mascaraque ${ }^{1,2} \mathbb{D}^{1}$, Pablo Delgado-Wicke ${ }^{1,2}$, Alejandra Damián ${ }^{1}$, \\ Silvia Rocío Lucena ${ }^{1,3}$, Elisa Carrasco ${ }^{1}$ (D) and Ángeles Juarranz ${ }^{1,2, *(1)}$ \\ 1 Departamento de Biología, Universidad Autónoma de Madrid, 28049 Madrid, Spain; \\ marta.mascaraque@uam.es (M.M.); pablo.delgado@uam.es (P.D.-W.); alejandra.damianv@gmail.com (A.D.); \\ silvialucenablas@gmail.com (S.R.L.); carrascoelisa@gmail.com (E.C.) \\ 2 Instituto Ramón y Cajal de Investigaciones Sanitarias, IRYCIS, 28034 Madrid, Spain \\ 3 Department of Basic Health Sciences, Faculty of Health Sciences, Rey Juan Carlos University, \\ 28922 Alcorcón, Madrid, Spain
}

Received: 1 February 2019; Accepted: 7 March 2019; Published: 11 March 2019

\begin{abstract}
Photodynamic therapy (PDT) constitutes a cancer treatment modality based on the administration of a photosensitizer, which accumulates in tumor cells. The subsequent irradiation of the tumoral area triggers the formation of reactive oxygen species responsible for cancer cell death. One of the compounds approved in clinical practice is methyl-aminolevulinate (MAL), a protoporphyrin IX (PpIX) precursor intermediate of heme synthesis. We have identified the mitotic catastrophe (MC) process after MAL-PDT in HeLa human carcinoma cells. The fluorescence microscopy revealed that PpIX was located mainly at plasma membrane and lysosomes of HeLa cells, although some fluorescence was also detected at endoplasmic reticulum and Golgi apparatus. Cell blockage at metaphase-anaphase transition was observed $24 \mathrm{~h}$ after PDT by phase contrast microscopy and flow cytometry. Mitotic apparatus components evaluation by immunofluorescence and Western blot indicated: multipolar spindles and disorganized chromosomes in the equatorial plate accompanied with dispersion of centromeres and alterations in aurora kinase proteins. The mitotic blockage induced by MAL-PDT resembled that induced by two compounds used in chemotherapy, taxol and nocodazole, both targeting microtubules. The alterations in tumoral cells provided evidence of MC induced by MAL-PDT, resolving mainly by apoptosis, directly or through the formation of multinucleate cells.
\end{abstract}

Keywords: photodynamic therapy; HeLa tumor cells; cell death; mitotic catastrophe; spindle elements

\section{Introduction}

Photodynamic therapy (PDT) is a minimally invasive treatment modality. Although still emerging, it is already a successful therapeutic procedure used for the management of oncologic and non-oncologic diseases [1,2]. Within the oncologic disorders, PDT presents an essential advantage due to the minimal side effects produced during and after treatment, through the specific actuation against malignant cells [3]. PDT is approved in clinics for the treatment of several forms of non-melanoma skin cancer [4] and also for lung and oesophageal neoplasias, among other type of cancers [5,6]. The therapy is based on the combination of three essential components: light, oxygen and a photosensitizer (PS). None of them are individually toxic, but their combination triggers the photodynamic reaction which is tumor ablative by generating highly reactive oxygen species (ROS), mainly singlet oxygen $\left({ }^{1} \mathrm{O}_{2}\right)[6]$. These molecules have short half-life and a destruction radius in the range of nanometers, being, therefore, the main targets the organelles where PSs are located $[7,8]$. The activation of the PS is obtained by irradiating with light of appropriate wavelength, generally in the red region of the 
visible spectrum (620-690 nm); with high capacity to deeply penetrate into the tissues [9]. The events initiated after PDT administration can lead to tumor cell death directly or indirectly by causing damage to tumor microvasculature and inducing a local inflammatory reaction [10]. More than a dozen compounds have been clinically approved or are in clinical trials for their use in PDT. Among them, there are the 5-aminolevulinic acid (ALA) and its ester derivatives, such as the methyl-aminolevulinate (MAL). Both are prodrugs commonly used in the clinical practice that are enzymatically turned into Protoporphyrin IX (PpIX), a potent PS [11].

It has been described that PDT can lead to the three main cell death pathways: apoptosis, necrosis and autophagy. The mode of cell death induced by this therapy depends on the type of tumor cell, the treatment doses and particularly the intracellular localization of the PS, which is related to the damage to specific organelle [12,13]. Different cell components can be targeted by PDT, including plasma membrane, lysosomes, mitochondria, Golgi apparatus, endoplasmic reticulum (ER), nuclei and cytoskeleton [14]. For instance, if the PS is localized in mitochondria PDT drives malignant cells mainly to apoptosis [15]. Otherwise, necrosis is the major cell death modality induced by PDT when compounds are localized in the plasma membrane, since treatment promotes then membrane permeability followed by the breaking down of cell components [16,17]. It has also been described that PDT irradiation of certain PSs, as the ER-localizing PS hypericin, can lead to cell autophagy [18]. This cell fate occurs when cell-repairing attempts in response to damage fail, triggering apoptosis in cancer cells [19].

The mitotic catastrophe (MC) had been previously defined as a type of cell death triggered by aberrant mitosis and executed either during mitosis or in the subsequent interphase [20]. According to the Nomenclature Committee on Cell Death, MC can constitute an oncosuppressive process that culminates in apoptotic, necrotic or senescence-mediated elimination of mitosis-deficient and genomically unstable cells [21]. Among the distinct therapeutic cellular targets that could drive to MC, cytoskeleton elements exhibit great relevance [22]. Targeting the cytoskeleton is an important goal for anticancer therapies since it plays significant roles in processes related to tumor progression such as cell mobility, division and vesicular transport [23]. In this sense, well-known chemotherapeutic components impeding microtubules (MTs) dynamics have been widely used in anticancer therapies, such as alkaloids, nocodazole (Nc) or toxoids, like taxol (Tx) [24,25]. In addition, there are several published works describing that MTs are affected by PDT by some PSs [14,24-26]. Specific PSs have been related to MC induction. Such treatments were able to induce cell cycle blockage at the metaphase-anaphase transition, which leads to MC followed directly by apoptosis and/or after the formation of giant cells [26,27].

Although the use of the metabolite MAL is clinically extended, the mechanisms underlying cancer cells death after MAL-PDT are not completely characterized. Here we present evidences indicating that MAL-PDT leads to MC in HeLa cells by affecting MTs dynamics and the expression and location of proteins implicated in mitotic regulation.

\section{Results}

\subsection{Cell Toxicity}

The PDT treatment combining MAL and red-light irradiation $(635 \mathrm{~nm})$ in carcinoma HeLa cells induced variable cell toxicity, determined by the MTT (3-(4,5-dimethylthiazol-2-yl)-2,5-diphenyltetrazolium bromide) assay. The toxicity was dependent on both; MAL concentration ( 0.3 or $1 \mathrm{mM}$ ) and light dose $\left(2.25-6.75 \mathrm{~J} / \mathrm{cm}^{2}\right)$ (Figure 1$)$. In contrast, cell viability of $\mathrm{HaCaT}$ cells, used as non-tumorigenic control cells, after the same treatments was always higher than $80 \%$, which supports the selectivity of the treatment. The incubation of HeLa and HaCaT with MAL ( 0.3 or $1 \mathrm{mM})$, in the absence of light, did not induce any significant toxicity. In the same way, no toxic effects were detected in the cells after red-light irradiation alone with the highest light dose used in this work $\left(6.75 \mathrm{~J} / \mathrm{cm}^{2}\right)$ (Table 1). Based on these results, we have established specific 
conditions as sublethal dose in HeLa cells for the rest of experiments (MAL $0.3 \mathrm{mM}$ and red light doses of $\left.2.25 \mathrm{~J} / \mathrm{cm}^{2}\right)$.



Figure 1. Phototoxicity induced by MAL-PDT (photodynamic therapy with methyl-aminolevulinate) in $\mathrm{HaCaT}$ (non-tumorigenic human keratinocytes cell line) and HeLa (cervical human carcinoma) cells. Cells were incubated with 0.3 or $1 \mathrm{mM}$ of MAL for $5 \mathrm{~h}$ and then irradiated with red light at variable doses. In HeLa cells, the response to MAL-PDT was dependent of the concentration of MAL and the light dose. HaCaT were not sensitive to these conditions of PDT. The photoeffects were evaluated by the MTT test $24 \mathrm{~h}$ after treatments. Each value corresponds to the mean obtained from three independent experiments $\pm \mathrm{SD} .\left({ }^{*} p<0.05 ;{ }^{* * *} p<0.001\right)$.

Table 1. Toxicity induced in HeLa and HaCaT cells by MAL or red light alone. Cells were incubated for $5 \mathrm{~h}$ with MAL at different concentrations or irradiated with the highest light dose used in the phototoxicity experiments. Toxicity was evaluated by the MTT test $24 \mathrm{~h}$ after treatments. Each value corresponds to the mean obtained from three independent experiments \pm SD.

\begin{tabular}{cccc}
\hline MAL Concentration $(\mathbf{m M})$ & Light Dose $\left(\mathbf{J} / \mathbf{c m}^{2}\right)$ & HeLa & HaCaT \\
\hline- & - & $98.9 \pm 1.10$ & $100 \pm 1.95$ \\
\hline 0.3 & - & $97.4 \pm 2.30$ & $104 \pm 0.01$ \\
\hline 1 & - & $104 \pm 5.17$ & $96.88 \pm 8.16$ \\
\hline- & 6.75 & $99.4 \pm 1.30$ & $101.69 \pm 3.68$ \\
\hline
\end{tabular}

\subsection{Subcellular Localization and Production of PpIX}

The intracellular localization of the PS, PpIX, produced from exogenous MAL, was evaluated by fluorescence microscopy under UV (365-390 nm) or green (510-550 nm) exciting light (Figure 2a,b). Control cells (without MAL) did not show red signal (Figure 2a). However, HeLa cells exhibited a red emission due to PpIX production after incubation with MAL ( $0.3 \mathrm{mM})$ for 5 or $24 \mathrm{~h}$. PpIX was located mainly at the plasma membrane (asterisks), although it was also observed diffusely in the cytoplasm and in some organelles (arrows), typically in a juxtanuclear position (Figure 2a). To determine the organelles in which PpIX was located, next we performed co-localization experiments with well-known biomarkers: for mitochondria (DIOC 6 ), lysosomes (LTG), endoplasmic reticulum (ER-BW) and Golgi apparatus (CellLight Golgi-GFP) (Figure 2b). Images taken at different excitation wavelengths, confirmed the localization observed when cells were incubated only with MAL and thus indicates that the positive juxtanuclear region corresponds mainly to lysosomes, and to a lesser extent, to the ER and Golgi apparatus.

Since we detected changes in the cellular response to PDT when using different treatment conditions, we analyzed by flow cytometry the levels of PpIX produced in HeLa cells (Figure 2c). The production of PpIX after $5 \mathrm{~h}$ of incubation with MAL resulted to be dependent on the MAL 
concentration ( $0.3 \mathrm{vs} 1 \mathrm{mM})$, whereas no significant differences were found due to the incubation times (5 vs. $24 \mathrm{~h}$ ) at each MAL concentration (Figure 2d). In contrast, PpIX production in HaCaT cells was independent of both MAL concentrations and incubation times in all the experimental conditions tested (Supplementary Figure S1). These results showed that HeLa cells produced higher levels of PpIX after $5 \mathrm{~h}$ of incubation with $1 \mathrm{mM}$ of MAL in comparison with $0.3 \mathrm{mM}$. 




Figure 2. Subcellular localization and production of PpIX. Cells were incubated with MAL ( 5 and $24 \mathrm{~h}$ ) and PpIX was observed in the fluorescence microscope under UV or green light irradiation. (a) Blue signal was mainly due to the autofluorescence of mitochondria, whereas the red signal, due to the PpIX production, was observed on the plasmatic membrane (asterisks) and diffuse in the cytoplasm (arrow). (b) Co-localization experiments of PpIX with different organelle markers. Cells were incubated for $24 \mathrm{~h}$ with $0.3 \mathrm{mM}$ MAL and with fluorescent probes for mitochondria (DIOC 6 ), lysosomes (LTG), endoplasmic reticulum (ER-BW), Golgi apparatus (Golgi-GFP). PpIX fluoresced in red whereas DIOC 6 , LTG and Golgi in green and ER in blue after green (510-550 nm), blue (450-490 nm) or UV (365-390 nm) exciting light, respectively. Arrow: organelle localization; asterisks: plasmatic membrane localization. (b') Percentage of co-localization of PpIX with the different organelles quantified by using FIJI software. (c) Representative data obtained from flow-cytometry analysis of the PpIX production, after 0.3 or $1 \mathrm{mM}$ MAL concentration, for $5 \mathrm{~h}$ of incubation. (d) PpIX production was relativized to its basal level in controls (not incubated with MAL). Each value corresponds to the mean obtained from three independent experiments \pm SD. $\left({ }^{*} p<0.05,{ }^{* *} p<0.01\right)$. Scale bar: $20 \mu \mathrm{m}$.

\subsection{Alterations in Cellular and Nuclear Morphology Triggered by PDT}

General and nuclear morphology was studied in the HeLa cell line after MAL-PDT with sublethal dose (0.3 mM MAL and $2.25 \mathrm{~J} / \mathrm{cm}^{2}$ red light), using phase contrast and fluorescence microscopy after 
staining with Höechst-33258 (Figure 3). Untreated HeLa cells presented a polygonal keratinocyte structure. The incubation with MAL or red light alone did not induce DNA damage (Supplementary Figure S2); whereas $5 \mathrm{~h}$ after PDT, the cells showed a slight cellular retraction and many rounded mitotic cells could be observed (not shown). After $24 \mathrm{~h}$ of MAL-PDT, cell cultures presented a high number of cells with division-characteristic morphologies (mainly metaphases, normal and abnormal with chromosome fragmentation), which indicates arrest in mitosis induced by the treatment (Supplementary Movie 1, control cells; and Supplementary Movie 2, MAL-PDT cells). After $48 \mathrm{~h}$ of PDT, cells appeared with multinucleate and apoptotic morphologies (cell rounding, blebbling and shrink cells with vesicles all over the cell surface and chromatin fragmentation) [28] (Figure 3a,b).

Cell cultures treated with the sublethal dose were analyzed by flow cytometry after labeling with propidium iodide (PI). Figure $3 \mathrm{c}$ shows the cell cycle distribution outlines and the percentages of cells in each cycle phase, comparing control cells with 24 and $48 \mathrm{~h}$ after PDT. Control cells presented a typical outline, with the G0-G1 frequency three times higher than G2-M, and low proportion of both, cell death and polyploidy. It can be noticed that 24 and $48 \mathrm{~h}$ after PDT there was a sharp decline of G0-G1 frequency, while there was an increase of G2-M. It was also observed an increment on the percentage of polyploidy cells (approximately from $2 \%$ to $7 \%$ ) $48 \mathrm{~h}$ after PDT. Finally, $48 \mathrm{~h}$ after PDT, the percentage of dead cells increased to $7 \%$. The synthesis phase was maintained stable over time. Together with the phase contrast images, all these data indicate a blockage in mitosis in response to PDT, with a subsequent activation of cell death mechanisms, while not rounded cells continued growing normally. 
(a)

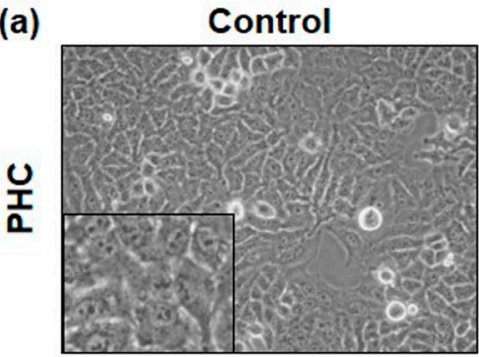

(b)


(c)

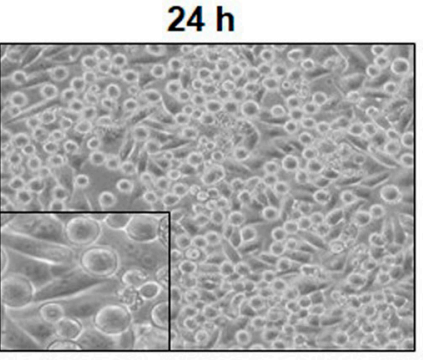

$24 \mathrm{~h}$



$48 \mathrm{~h}$


$24 \mathrm{~h}$

$48 \mathrm{~h}$

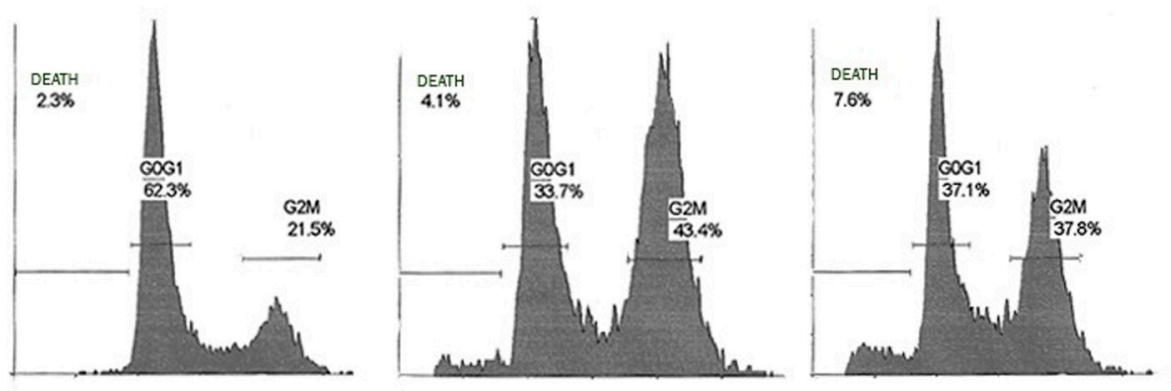

Figure 3. Cellular and nuclear morphology in control cells and after PDT (photodynamic therapy). Cells were observed by phase contrast microscopy (PHC). (a) Control HeLa cells presented an epithelial aspect; after $24 \mathrm{~h}$ treatment a high number of rounded mitotic cells could be seen in the cultures; after $48 \mathrm{~h}$ treatment, cells with multinucleated morphology appeared in the cultures (asterisk) and apoptotic morphologies. Scale bar: $100 \mu \mathrm{m}$; inserts $10 \mu \mathrm{m}$. (b) PHC and nuclei morphology observed by fluorescence microscopy after Höechst-33258 staining, after $24 \mathrm{~h}$ PDT mainly metaphases, normal and abnormal with chromosome fragmentation and after $48 \mathrm{~h}$ PDT apoptotic morphology. (c) Cell cycle distribution outlines in each cell cycle phase 0,24 and $48 \mathrm{~h}$ after PDT. Scale bar: $20 \mu \mathrm{m}$.

These studies were complemented with analyses by fluorescence microscopy after staining unfixed cells (floating and attached) with ethidium bromide (EB) and acridine orange (AO). After $24 \mathrm{~h}$ of MAL-PDT with the sublethal dose, these assays allowed us to distinguish viable, dividing and multinucleated cells all fluorescing in green, as well as dead/apoptotic cell morphologies, fluorescing in red (Figure 4a).

In order to investigate the mechanism by which PDT caused mitotic blockage in HeLa cells, we treated the cells in parallel with two known anti-cancer drugs, whose target are MTs: Tx and Nc. Treatment of HeLa cells with these compounds $(0.05 \mu \mathrm{M}$ Tx or $0.25 \mu \mathrm{M} \mathrm{Nc})$ caused the well-known mitotic arrest and characteristic nuclei morphologies, which were quite similar to those described after the application of MAL-PDT (Figure 4b). The number of cells with the morphologies described after 
different treatments and the EB-AO staining is shown in Figure 4c. PDT caused a significant increase of $47.5 \%$ of rounded dividing cells $24 \mathrm{~h}$ after treatment with respect to the control. At $48 \mathrm{~h}$ since after the treatment, the percentage of rounded cells was halved, and that of viable and multinucleated cells increased significantly. Tx and Nc treated cultures displayed an elevated percentage of cells in mitosis (65\% and 39\%, respectively) $24 \mathrm{~h}$ after treatment. After $48 \mathrm{~h}$, as in PDT cells, the percentages of dividing cells also decreased, while apoptotic and multinucleated cells were more frequent.

(a)

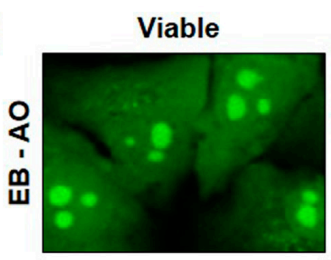

(b)

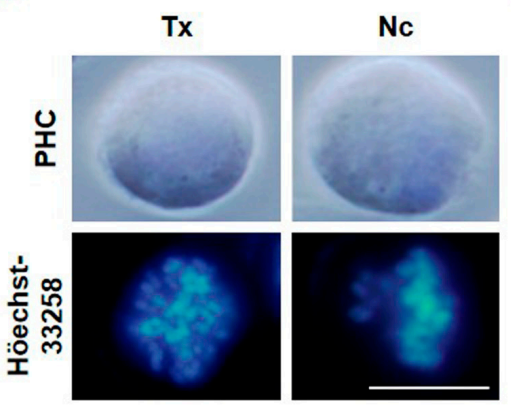

Apoptosis

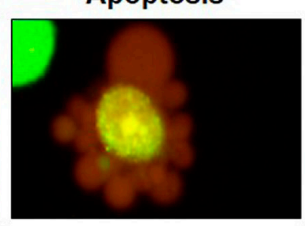

(c)

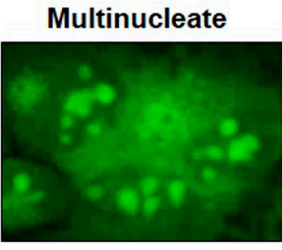

Division

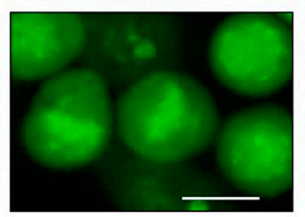

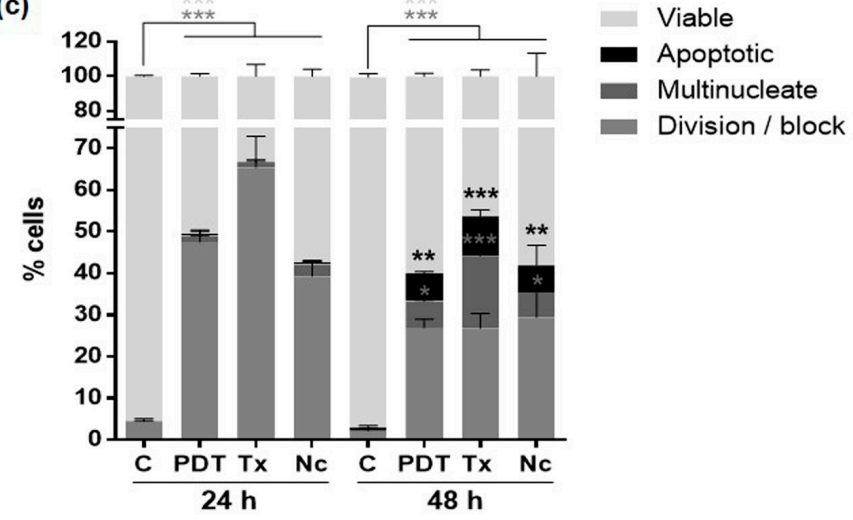

Figure 4. Morphology classification after fluorochome staining. (a) In vivo analysis $24 \mathrm{~h}$ after MAL-PDT by fluorescence microscopy after ethidium bromide (EB)-acridine orange (AO) staining. This staining allows differentiating between: (1) viable (fluorescing in green due to AO) (2) apoptotic (fluorescing in red/yellowish due to AO/EB), (3) multinucleate, and (4) dividing cells. (b) Cellular and nuclear morphology $24 \mathrm{~h}$ after treatment with $0.05 \mu \mathrm{M}$ Tx or $0.25 \mu \mathrm{M}$ Nc observed by PHC or Höechst-33258. (c) Percentage of viable, dividing, apoptotic and multinucleated cells 24 and $48 \mathrm{~h}$ after treatments application (values relative to control cells) $\left({ }^{*} p<0.05 ;{ }^{* *} p<0.01 ;{ }^{* * *} p<0.001\right)$. C: Control; Tx: taxol; Nc: nocodazole. Scale bar: $10 \mu \mathrm{m}$.

\subsection{MAL-PDT Induces Microtubule Alterations in the HeLa Line}

Cytoskeleton components are involved, among other physiopathological functions, in cell proliferation as well as metastasis. Among them, MTs are implicated in the formation of the mitotic spindle in dividing cells $[29,30]$. The evaluation of MTs alterations caused by MAL-PDT was carried out by indirect immunofluorescence (IF) for $\alpha$-tubulin 5, 24 and $48 \mathrm{~h}$ after treatment. Control cells in interphase showed a well-developed microtubular network formed from the juxtanuclear organizing region (Figure 5a) and cells in division exhibited well-organized bipolar mitotic spindles with the chromosomes aligned on the equatorial plate (Figure 5b). At $5 \mathrm{~h}$ after PDT, cells in interphase showed retraction accompanied with some MT disorganization (Supplementary Figure S3). The most important changes were observed $24 \mathrm{~h}$ after MAL-PDT increasing the mitotic index (MI) compared to untreated control cultures as previously indicated. In addition, $85 \%$ of dividing cells were undergoing metaphase $24 \mathrm{~h}$ after PDT while in control cells equivalent to $25 \%$. The majority of the mitotic spindles presented an abnormal morphology (multipolar and aberrant bipolar figures) being $87 \%$ of total metaphase after $24 \mathrm{~h}$ PDT (Figure 5a). Figure 5b shows representative images of normal and abnormal metaphases, differentiating between multipolar (Figure 5b-1) and aberrant bipolar with altered disposition chromosome on the equatorial plate (Figure 5b-2). The number of cells in division, 
also with altered spindles, $48 \mathrm{~h}$ after PDT was still high, and multinucleated and giant cells appeared corresponding to cells that have entered in G1 (Supplementary Figure S3).

The results obtained after MAL-PDT regarding MTs organization/disposition were compared to those induced by the treatment with Tx or Nc. After $24 \mathrm{~h}$ of Tx treatment, the majority of dividing cells showed multipolar spindles and chromosomal fragmentation; Nc induced mostly bipolar spindles with disorganized chromosomes in the equatorial plate (Figure 5b). The altered disposition of the chromosomes was confirmed by IF for $\alpha$-tubulin and anti-centromere antibodies (ACA) (Figure 5b). These data, along with the morphological assays, suggest that MAL-PDT induces MC in HeLa tumoral cells by targeting MTs.

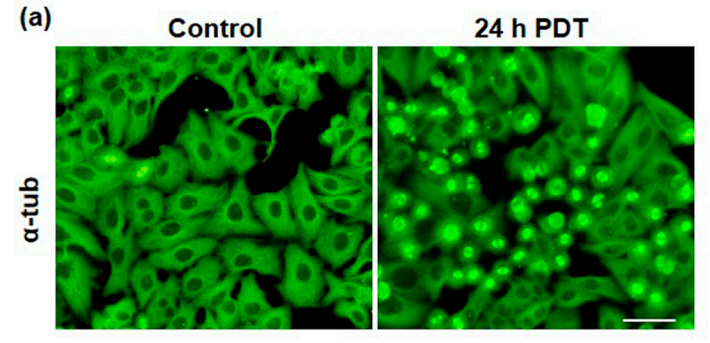

(b)

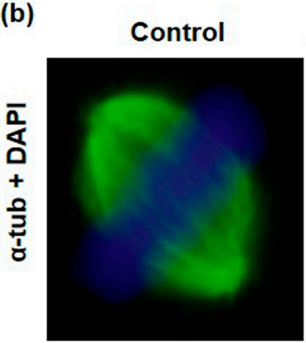

(c)

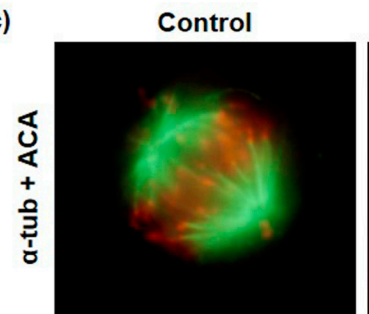

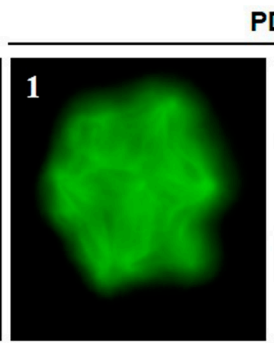

PDT

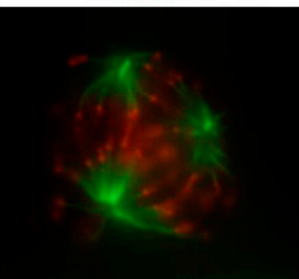

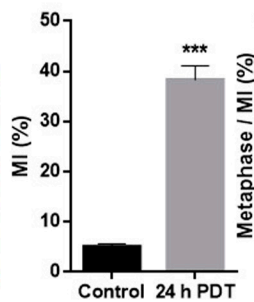
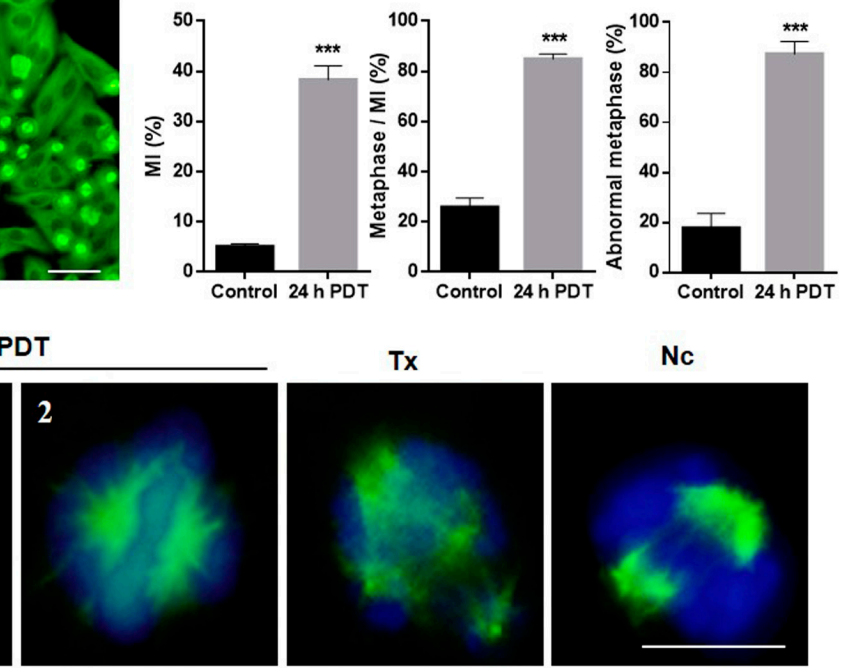

$\mathrm{Tx}$
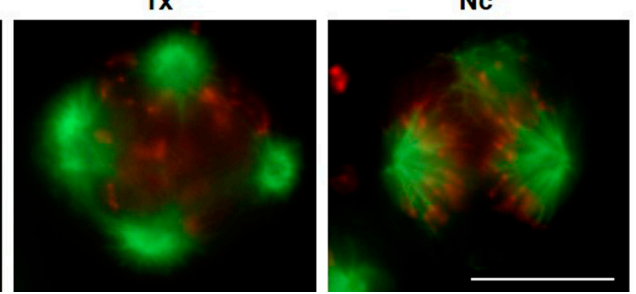

Figure 5. Microtubular and chromosomal alterations after PDT. Cells were evaluated $24 \mathrm{~h}$ after treatments by IF for $\alpha$-tubulin. (a) Morphological changes in $\alpha$-tubulin after $24 \mathrm{~h}$ PDT. Mitotic index, number of metaphases/MI and percentage of abnormal metaphases (*** $p<0.001)$. Scale bar: $50 \mu \mathrm{m}$. (b) Mitotic spindles of control and after MAL-PDT, Tx and Nc treated cells showing normal and altered morphology, respectively. DNA was stained with DAPI. (1) Multipolar cell, (2) aberrant bipolar with altered disposition chromosome on the equatorial plate. Scale bar: $10 \mu \mathrm{m}$. (c) Mitotic spindles (fluorescing in green) and centromeres (fluorescing in red) determined by IF for $\alpha$-tubulin and ACA, respectively. Scale bar: $10 \mu \mathrm{m}$.

\subsection{Localization and Expression of Proteins Involved in Cell Division after MAL-PDT}

In order to approach the cellular/molecular mechanism involved in the mitotic blockage and MC process, the expression pattern of different proteins implicated in these processes was evaluated by indirect IF and Western blot (WB). The first two molecules analyzed were aurora kinase A and B (AURK A and AURK B). AURK A collaborates in the regulation of entry into mitosis, helpful in centrosome maturation [31]. In HeLa control cells AURK A was located around the centrosomes and pericentriolar material in prophase; in prometaphase and metaphase on both sides of the poles according to the duplication of the centrosomes, and during anaphase was localized predominantly around the polar MTs, although a scattered signal was found in the middle body 
(Supplementary Figure S4a). In the case of cells treated with PDT, Tx or Nc, a more intense AURK A signal was visualized at the centrosome level, either with localization similar to that of the control, or disperse, with multiple signals, in multipolar cells (Figure 6a). This result coincides with that observed by IF for $\alpha$-tubulin in cells with multiple poles.

AURK B, related to the regulation of anaphase output, centromere regulating correct chromosome alignment and segregation during mitosis [31]. In control cells was located in the centromeres in metaphase, in middle body and in the equatorial plate in anaphase and in telophase, cytokinesis and early G1 it was located in the dividing furrow (Supplementary Figure S4b). In cells treated with PDT, in general, a similar location to control HeLa cells was observed, except in those cells with an aberrant morphology of the mitotic spindle, as in case of tripolar cells, which presented AURK B in the middle body. The cells in mitotic arrest treated with Tx and Nc showed a scattered signal of AURK B, coinciding with the non-alignment of the chromosomes in the equatorial plate (Figure 6b).

In relation to this, an increase in cyclin B1 was observed $24 \mathrm{~h}$ after treatments, which correlates with the increase shown in dividing cells (G2/M) (Figure 6c). Cyclin B1 has a crucial function in cell division and its degradation is essential for exiting mitosis by activation of the anaphase-promoting complex (APC) [32].

Finally, due to the important role of $\gamma \mathrm{H}_{2} \mathrm{~A} . \mathrm{X}$ in MC, we assessed its expression in HeLa cells $24 \mathrm{~h}$ after treatment (Figure 6d). As expected, control cells in interphase did not show expression of $\gamma \mathrm{H}_{2}$ A.X, only cells in division exhibited expression of the protein, necessary for the correct condensation of DNA during division. After MAL-PDT, both cells blocked in division as well as multinucleated cells positively expressed the protein. The percentage of positive control cells for $\gamma \mathrm{H}_{2} \mathrm{~A}$.X was $12 \%$ whereas in treated cultures was $65 \%$. 
(a)
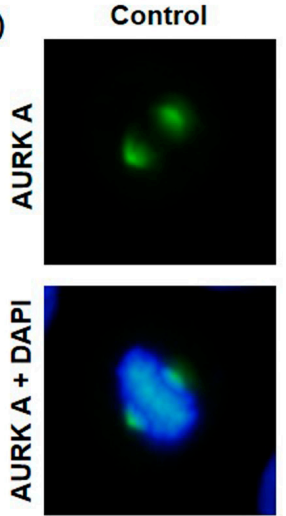

(b)
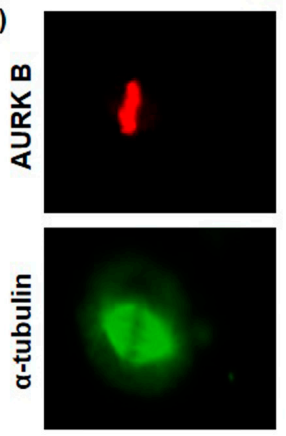

PDT


Tx


Nc
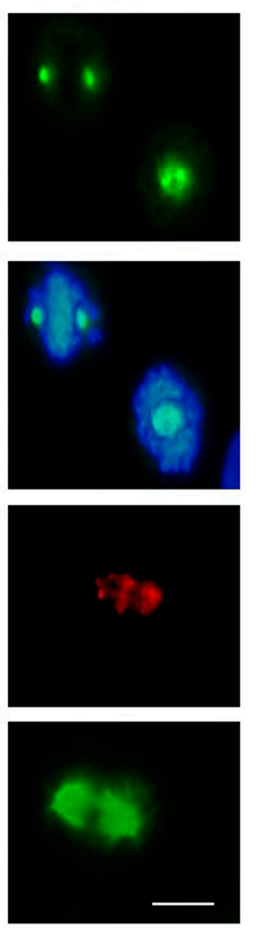

(c)



(d)

Control
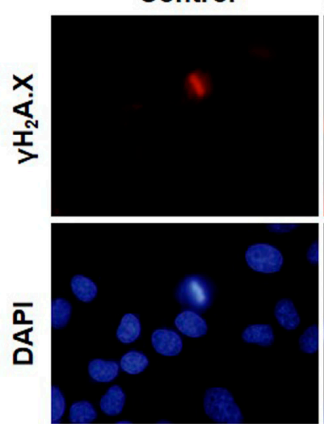

PDT

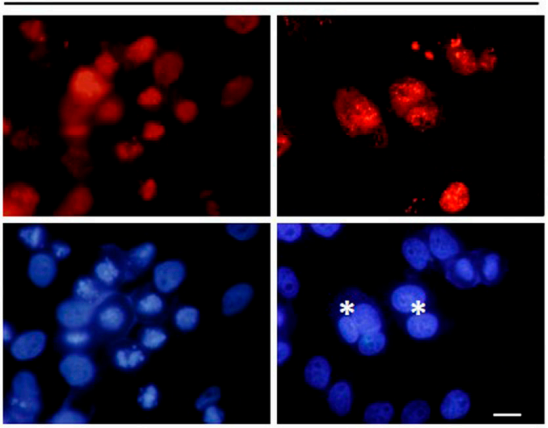

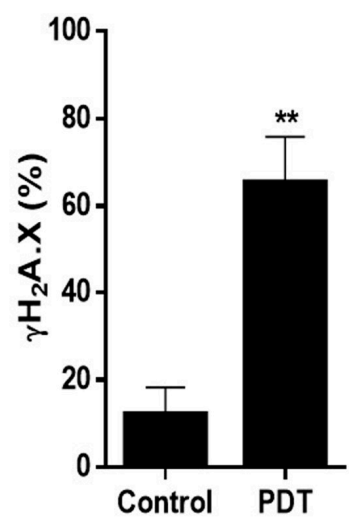

Figure 6. Localization and expression of proteins involved in cell division. (a) Localization of AURK A $24 \mathrm{~h}$ after treatment of PDT, Tx and Nc; the protein appears situated at the centrosome level. (b) Localization of AURK B after $24 \mathrm{~h}$ treatment of PDT, Tx and Nc; the protein was observed at chromosome level. (c) WB analyses of cyclin B1 and $\alpha$-tubulin 24 and $48 \mathrm{~h}$ after the treatments. (d) Representation of positive HeLa cells by IF of $\gamma \mathrm{H}_{2} \mathrm{~A}$.X in control and after PDT; asterisk: multinucleate cells. Scale bar: $10 \mu \mathrm{m}$. (** $p<0.01)$.

\subsection{Mechanism of Cell Death}

The general morphology of dead cells (observed by phase contrast microscopy), of nuclei (observed by fluorescence microscopy after Höechst-33258 staining) and the sub G1 phase (detected by flow cytometry) (see Figure 3) allowed us to postulate that MC induced by the sublethal PDT dose applied to HeLa cancer cells was mainly resolved by apoptosis. To confirm this hypothesis, HeLa cells were incubated with Z-VAD-FMK (broad-spectrum caspase inhibitor) before MAL-PDT. The results obtained showed that the caspase inhibitor protects the cells against apoptosis inducing an increase in cell survival (Figure 7a). Finally, we analyzed the expression of caspase 2 and 3 ; the first one implicated 
in activating MC and the second one in general apoptosis. Both caspases increased their expression consecutively, 24 and $48 \mathrm{~h}$ after PDT (Figure $7 \mathrm{~b}$ ). All these results indicate that the mechanism of cell death involved the participation of caspase and considering the results obtained by the morphology analysis, we concluded that MC was being resolved by apoptosis.

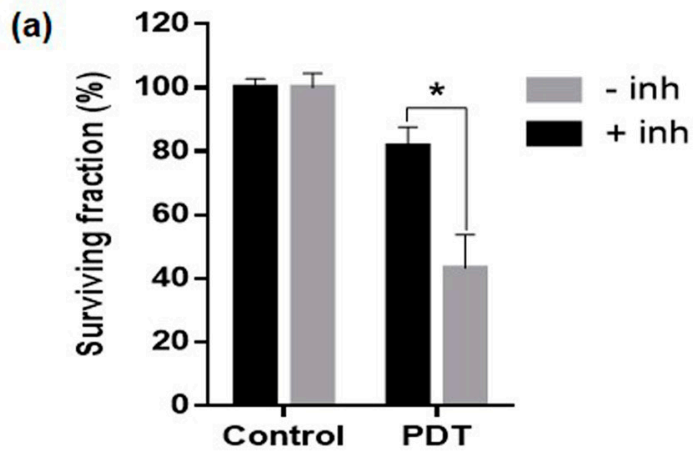

(b)

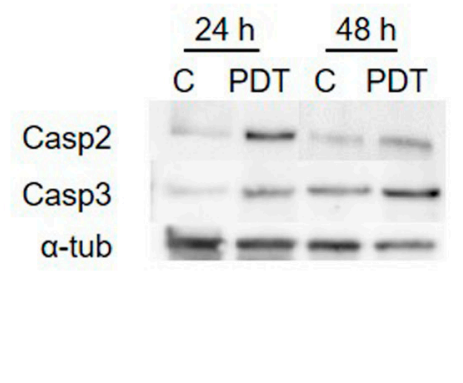

Figure 7. Mechanism of cell death. (a) Cell survival percentage after $24 \mathrm{~h}$ PDT with or without caspase inhibitor Z-VAD-FMK. (b) WB analysis of caspase 2, caspase 3 and $\alpha$-tubulin 24 and $48 \mathrm{~h}$ after PDT. $(* p<0.05)$.

\section{Discussion}

The present in vitro study provides evidences of induction of MC in HeLa cells after MAL-PDT through MTs disruption and deregulation of the expression of key cell cycle proteins. Based on the specific accumulation of the PS in the tumor cells and subsequent irradiation with visible light, PDT enables maintenance of healthy cells while malignant cells are eradicated [1-3]. It has been broadly described that the main cell death pathways induced by PDT are apoptosis, necrosis and autophagy. However, less is known about the processes leading to them via MC [12]. In particular, nothing has been described about MAL-PDT as potential inductor of MC. This process had been described as a cell death mechanism related with defective mitosis regulation that leads to cell cycle arrest, mitotic spindle abnormalities, multipolar division, altered chromosome arrangement, aneuploidy and, finally, cell death [33]. Much of the treatments triggering this cellular response target cytoskeleton components, MTs in particular, or induce DNA damage [24,25]. Up to now, a few PSs have been clinically approved, including MAL, precursor of the endogenous PS PpIX, which presents a huge relevance in the topical treatment of non-melanoma skin cancer and the precancerous lesion actinic keratosis [34,35]. Despite of being currently a common treatment, cases of resistance or recurrence have been described [36,37]. Therefore, deeper

to prevent negative responses to PDT and to improve this therapy.

In this sense, by using HaCaT as a non-tumorigenic control cell line and the widely studied carcinoma cell line HeLa, we first evaluated the efficacy of PDT. Neither the light nor the prodrug individually administrated induced cell death. In addition, while HeLa cells were affected by PDT in a red-light $\left(2.25-6.75 \mathrm{~J} / \mathrm{cm}^{2}\right)$ and MAL $(0.3$ or $1 \mathrm{mM})$ dose-dependent manner, HaCaT cells remained almost unaltered. These results confirmed PDT selectivity destroying cancer cells $[1-3,6]$. From the obtained results, we selected specific conditions to perform the rest of the experiments that induced a sublethal toxicity (lower than 50\%) in HeLa population: $0.3 \mathrm{mM} \mathrm{MAL}, 5 \mathrm{~h}$ of incubation and $2.25 \mathrm{~J} / \mathrm{cm}^{2}$ of red-light dose.

It has been established that the cell death pathway followed by cancer cells after PDT is directly related to, among others, subcellular location of the PS employed [12,15]. In that context, the studies performed on subcellular localization of PpIX in HeLa cells after MAL incubation indicated that the PS was accumulated mainly in plasma membrane and in cytoplasm and no differences were observed after the MAL incubation times evaluated ( 5 and $24 \mathrm{~h}$ ). In addition, our co-localization studies showed that MAL induced PpIX were also located at lysosomes and Golgi apparatus level, without ruling out the 
possible presence of PS in the ER. These results are in disagreement with those obtained in oesophageal carcinoma cells, where ALA-induced PpIX appeared in the mitochondria [38]. Chen, R. et al., reported that ALA-induced PpIX location in DHL (follicular lymphoma) cells was detected mainly in ER and mitochondria, but also in lower levels in the lysosomes [39]. From all these results, it is tempting to consider that once PpIX is produced in the mitochondria, it can reach to other organelles, in our case, mainly the cell membrane, cytoplasm, lysosomes and Golgi apparatus.

In addition to PS intracellular location and ROS-generated in that specific area, PpIX intracellular concentration has also shown great relevance in PDT effectiveness. In our case, PpIX accumulation increased with MAL concentration, which was consistent with the decrease in cell viability found with the MAL dose used in this work. These results also support previously published data indicating that an increase in PpIX production is related to an increase in the induction of cell death tumor cells being directly associated with a higher ROS production [40].

Morphological evaluation of PDT HeLa cell cultures showed cell retraction a few hours after the treatment and cell rounding, being more evident 24 and $48 \mathrm{~h}$ later. This result suggests that MAL-PDT was inducing mitotic arrest at metaphase-anaphase transition. In fact, $24 \mathrm{~h}$ after MAL-PDT we detected a MI of $40 \%$, in contrast with only $5 \%$ in control cells. In addition, most of the cells in division were in metaphase and exhibited abnormal MTs morphologies. After $48 \mathrm{~h}$, the number of giant cells with macronuclei and multinucleated cells increased, revealing an increment in endoreplication. We also determined an increase in cells with apoptotic features. These morphological observations were confirmed by flow cytometry, reflecting an abnormal distribution of the treated cultures among the cell cycle phases both 24 and $48 \mathrm{~h}$ after MAL-PDT. A sudden decline of the G0-G1 frequency was appreciated, followed by an increase in G2-M at both times points evaluated after the treatment. Furthermore, $48 \mathrm{~h}$ after PDT there was an increment in the proportion of multinucleated cells and dead cells. These data suggest that after accumulation in G2-M, some cells could skip the blockage and continue their cycle giving rise to a higher number of aneuploidies and greater genomic instability which could lead, as a consequence, to more aggressive and resistant tumors [33,41].

All the aforementioned results support that cells were blocked at mitosis with a subsequent activation of cell death processes that could be explained by MC induction and resolution. This mechanism can occur after different situations of cell damage: due to MTs impairment, problems affecting the mitotic machinery sensed during the $M$ phase or chromosomal defects [26,33]. Accordingly, MTs due to their role in cell division constitute a fundamental target for antineoplastic treatments, such as Tx and Nc [30,42]. Tx is a MT stabilizing agent that binds with high affinity to polymerized tubulin. It promotes the growth of these cytoskeletal elements and inhibits their disassembly, blocking the cell cycle in the transition from metaphase to anaphase, inducing finally apoptosis [43,44]. Cells in the presence of Tx cause an activation of APC, complex that promote the anaphase, that favors the reduction of cyclin B1 levels and, therefore, the early exit of mitosis by slippage [44]. On the other hand, Nc is a MT destabilizing agent that has been observed leading to cell blockage in the metaphase-anaphase transition [45]. In this sense, after MAL-PDT the same effects of those induced by Tx and Nc treatments in HeLa cells were observed: mitotic blockage, spindle abnormalities, disorganization of chromosomes, multipolar cell division, and generation of daughter cells with macronuclei or multinucleated.

In addition, the assessment of protein expression by IF or WB revealed modifications in molecules related to cell division after PDT treatment. AURK A exhibited a very similar location and expression pattern in great number of treated cells than in the control, but was increased in cells with two or more centrosomes, indicating a potential increase in the AURK A synthesis $[46,47]$ as a consequence of centrosome amplification in response as the ROS produced after PDT, as it has been previously described [48]. In addition, AURK B and ACA were dispersed in their location indicating absence of alignment of the chromosomes in the equatorial plate at metaphase. All these results support that MTs are an essential target of PDT with MAL, as occurs with other PSs [14,24-26]. 
Another fundamental protein in cell division is cyclin B1. In this sense, an increase in the expression levels of this protein accompanied with mitosis blockage have been described after Nc treatment [49]. In line with previous work by other authors, this study has shown an increase in the expression of cyclin B1 $24 \mathrm{~h}$ after PDT, Tx and Nc treatments.

In keeping with this, double strand DNA breaks (DSB) in mammalian chromosomes lead to $\mathrm{S} 139$ phosphorylation of the $\mathrm{H}_{2} \mathrm{AX}$ histone, also called gamma- $\mathrm{H}_{2} \mathrm{AX}\left(\gamma \mathrm{H}_{2} \mathrm{~A}\right.$.X). This phosphorylated histone is required as a checkpoint for cell cycle arrest and DNA repair against DSB [50]. Therefore, the increase in the expression of $\gamma \mathrm{H}_{2} \mathrm{~A}$.X observed after PDT indicates DNA damage like a factor of MC.

All these results confirm that the application of sublethal doses of PDT in HeLa cells induces MC, as it has also been described in other studies using different cell lines and PSs [26,27], indicating that the effects caused by them are similar to those of the anti-carcinogenic agents Tx and Nc [42-45].

Finally, MC can be resolved in different ways: (a) cells directly die without exiting mitosis; (b) reach the G1 phase of the subsequent cell cycle (through a phenomenon that is known as mitotic slippage, which generates giant cells and then dies); (c) exit mitosis and undergo senescence [21]. In this study, we have observed an increase in multinucleated and apoptotic morphologies $48 \mathrm{~h}$ after PDT, which was prevented by the caspase inhibitor Z-VAD-FMK. In addition, our results indicate an increase in the expression of caspase-2, followed by the increment of caspase- 3 expression and the condensation of chromatin 24 and $48 \mathrm{~h}$ after PDT, indicating that apoptosis via MC was happening as it has been reported in other studies with other PS compounds [51,52].

In summary, the present study shows that MAL-PDT in HeLa cells induce MC, altering both the dynamics of MTs and chromosome arrangement. MC was finally resolved by slippage or apoptosis. A greater knowledge of the response related to tumoral cell death mechanism triggered after MAL-PDT could contribute to optimize this therapy to avoid potential tumor recurrences.

\section{Materials and Methods}

\subsection{Cell Culture}

For the in vitro studies, we used HaCaT cells, a spontaneously transformed but non-tumorigenic human keratinocytes cell line (Cell Line Service, Eppelheim, Germany) and the human HeLa carcinoma cell line (obtained from ATCC), used as reference in vitro control in many laboratories focused on PDT action. Cells were routinely grown as a monolayer in F25 flasks (Fisher) or culture dishes with or without glass coverslips (Menzel-Gläser) placed inside the dishes, using Dulbecco's modified Eagle's medium (DMEM) supplemented with 10\% $(v / v)$ fetal bovine serum (FBS), 50 units $/ \mathrm{mL}$ penicillin, and $50 \mathrm{\mu g} / \mathrm{mL}$ streptomycin (all from Gibco, Paisley, UK). Cell cultures were performed in an incubator with $5 \%$ of $\mathrm{CO} 2$ at $37{ }^{\circ} \mathrm{C}$ and $95 \%$ humidity. Treatments were performed when cultures reached a $60-70 \%$ confluence.

\subsection{Reagents and Antibodies}

Methyl-aminolevulinate (MAL), Taxol (Tx) and Nocodazole (NC) were obtained from Sigma-Aldrich (St. Louis, MO, USA). The broad-spectrum caspase inhibitor benzylocarbonyl-Val-Ala-Asp-fluoromethyl ketone (Z-VAD-fmk) was purchased by BD Biosciences (Villeurbanne, France). MTT (3-(4,5-dimethylthiazol-2-yl)-2,5-diphenyltetrazolium bromide) (Sigma-Aldrich, St Louis, MO, USA). The following primary antibodies were used: mouse anti $\alpha$-tubulin (Sigma-Aldrich), mouse anti AURKA (Abcam, Boston, MA, USA), mouse anti $\beta$-actin (Sigma-Aldrich), rabbit anti AURKB (Abcam), rabbit anti P-H ${ }_{2}$ A.X (S139) (Cell Signaling Technology, Danvers, MA, USA), rabbit anti caspase 3 (NeoMarkers, Fremont, CA USA); mouse anti caspase 2 (BD Biosciences, Villeurbanne, France), mouse anti cyclin B1 (Biosource, Nivelles, Belgium) and Human ACA-Texas Red (Antibodies Incorporated, Davis, CA, USA). The secondary antibodies used were: mouse IgG-Alexa 488 and rabbit IgG-Alexa 546 (Invitrogen, Carlsbad, CA, USA), mouse IgG Peroxidase and rabbit IgG Peroxidase (Thermo Scientific, Rockford, IL, USA). Fluorescent 
markers were: $3^{\prime}$ dihexyloxocarbocyanine iodide (DIOC6) for mitochondria, Lysotracker Green (LTG) for lysosomes, ER-Tracker Blue White-DPX for endoplasmic reticulum and CellLight Golgi-GFP marker for Golgi apparatus (all of them from Invitrogen, Carlsbad, CA, USA). Höechst-33258 (Riedel-de Haën, Hannover, Germany), acridine orange (AO) (BDH, Poole, UK) and ethidium bromide (EB) (Sigma-Aldrich) were used for cellular staining.

\subsection{Treatments}

For PDT, MAL was prepared at an initial concentration of $10 \mathrm{mM}$ in deionized sterile water. For phototreatments, cells were cultured in plates of 24 wells and incubated $5 \mathrm{~h}$ with appropriated MAL concentrations ( 0.3 and $1 \mathrm{mM}$ ) in DMEM culture medium without FBS. Afterwards, cells were irradiated with variable light doses $\left(2.25\right.$ to $\left.6.75 \mathrm{~J} / \mathrm{cm}^{2}\right)$ by using a red-light emitting diode source (WP7143 SURC/E Kingsbright) with an irradiation intensity of $6.2 \mathrm{~mW} / \mathrm{cm}^{2}$ (as measured by Coherent Lasermate powermeter) and a emission peak at $\lambda=634 \pm 20 \mathrm{~nm}$. To minimize light refraction, cells were irradiated from the bottom of the plates (Supplementary Figure S5a). After irradiation, the medium containing MAL was changed by DMEM with $10 \%$ of FBS. We have observed that the presence or absence of MAL during irradiation did not affect HeLa cell viability (evaluated by the MTT assay, see below) (Supplementary Figure S5b). Therefore, from these observations, cell irradiation was performed in the presence of MAL. Time-lapse microscopy was used to evaluate the mitotic blockage process by taking images each $30 \mathrm{~min}$ for a total of $24 \mathrm{~h}$ using a digital Leica inverted microscope DMI $6000 \mathrm{~B}$. In order to evaluate the implication of caspase enzymes in the cell death process induced by PDT, cells were incubated with $25 \mu \mathrm{M}$ (final concentration) of Z-VAD-fmk for $5 \mathrm{~h}$ in presence of MAL before light irradiation. The inhibitor binds to the catalytic site of caspases blocking apoptosis. After irradiation, the cells were incubated in complete medium for $24 \mathrm{~h}$ at $37{ }^{\circ} \mathrm{C}$ until evaluation. The experiments were repeated at least three times. For cellular drug-induced blockage, HeLa cells were treated with Tx that promotes MTs stabilization or Nc, a MT assembly inhibitor. When cultures reached $60 \%$ confluence, cells were treated for 24 or $48 \mathrm{~h}$ with $5 \times 10^{-8} \mathrm{M}$ of Tx and $2.5 \times 10^{-7} \mathrm{M}$ of Nc prepared in DMEM with $10 \%$ FBS [26].

\subsection{Cellular Toxicity}

Toxicity of the different concentrations of MAL alone or followed by red-light irradiation on HeLa and HaCaT cells was evaluated $24 \mathrm{~h}$ after treatments by the MTT assay. This method is widely accepted as a quantitative colorimetric assay for cell toxicity and it is based on active cell metabolism. After treatments, cells were incubated with MTT (at a final of $50 \mu \mathrm{g} / \mathrm{mL}$ ) at $37^{\circ} \mathrm{C}$ for $3 \mathrm{~h}$, the culture medium was then removed, and the precipitated formazan was dissolved in DMSO. Absorption was measured at $542 \mathrm{~nm}$ in a spectrophotometer (Espectra Fluor 4, Tecan, Bradenton, FL, USA). Cellular toxicity was expressed as the percentage of formazan absorption from MAL-PDT cells compared to control cells (which received neither MAL nor PDT). To test the effect of light only on cell toxicity, we performed control experiments using only the red-light irradiation on cells $6.75 \mathrm{~J} / \mathrm{cm}^{2}$, the highest dose used in this work. The results obtained are shown as mean values and standard deviations from three independent experiments.

\subsection{Morphological Studies}

Changes in cell morphology after PDT were analyzed using bright field illumination, or fluorescence microscopy after staining with Höechst-33258. At different times after treatments (24-48 h), floating (detached) cells in the culture medium were collected from each dish and centrifuged at $1000 \mathrm{rpm}$ for $5 \mathrm{~min}$, the supernatant was eliminated and cells were fixed with $50 \mu \mathrm{L} 70 \%$ ethanol $\left(-20^{\circ} \mathrm{C}\right)$. Nuclei of detached cells were stained by adding $5 \mu \mathrm{L}$ of Höechst-33258 $(1 \mathrm{mg} / \mathrm{mL})$. The type of cell death was determined analyzing nuclei morphology according to morphological criteria previously published [28]. The staining of the cells with AO-EB allowed distinguishing between viable and dead cells. After 24 or $48 \mathrm{~h}$ of the treatments (PDT, Tx or Nc), EB and AO were added to the 
cultures at a final concentration of $50 \mu \mathrm{g} / \mathrm{mL}$. Immediately after EB-AO staining cells were observed by fluorescence microscope under blue excitation light. According to the fluorescence color observed, cells were classified as follows: viable and dead cells fluorescing in green or orange, respectively [53]. In addition, the AO-EB staining allowed distinguishing cells in mitosis, and with rounded morphology. At least 500 cells were counted for each treatment condition.

\subsection{Subcellular Localization of $M A L$}

Cells were grown on coverslips and when they reached around $70 \%$ of confluence, were incubated with MAL $0.3 \mathrm{mM}$ either for 5 or $24 \mathrm{~h}$ at $37^{\circ} \mathrm{C}$. Then, cells were briefly washed with PBS (phosphate buffered saline), mounted on slides and observed in situ with a fluorescence microscope using UV excitation light. The subcellular localization was analyzed comparing the fluorescent signal pattern emitted by PpIX with that obtained by fluorescent markers of known selective subcellular accumulation: 3,3' dihexyloxocarbocyanine iodide (DIOC6) for mitochondria, Lysotracker Green (LTG) for lysosomes, ER-Tracker Blue White-DPX for endoplasmic reticulum and CellLight Golgi-GFP marker for Golgi apparatus following the instructions given by the manufacturers. For that, cells were incubated with MAL $0.3 \mathrm{mM}$ for $24 \mathrm{~h}$, and the cells were further incubated for $5 \mathrm{~min}$ with the markers. For Golgi apparatus co-localization studies, cells were co-incubated with MAL and CellLight Golgi-GFP for $18 \mathrm{~h}$. The co-localization assays were performed twice and evaluated using the Olympus fluorescence microscope using the appropriate filter sets. Quantification of percentage of co-localization was performed using FIJI software (available online: http:/ / fiji.sc/Fiji), which is an open source image-processing package based on ImageJ software (National Institutes of Health, Bethesda, MD, USA). We first established, separately, the threshold for positive cells in PpIX and in the organelle marker fluorescent images, obtained under the corresponding exiting light: UV (360-390 nm), blue (450-490 nm) and green (510-550 nm). The positive PpIX area as well as that shared with the fluorescent organelle marker was measured. Then, the percentage of shared positivity with respect to the organelle marker was calculated. At least the fluorescence of 100 cells were measured with the corresponding exciting lights.

\subsection{Determination of Intracellular Synthesis of PpIX}

Cells grown in F25 were incubated with 0.3 or $1 \mathrm{mM}$ MAL for $5 \mathrm{~h}$ or $24 \mathrm{~h}$. Then, cells were washed with PBS, trypsinized and centrifuged for $10 \mathrm{~min}$ at $2000 \mathrm{rpm}$. After centrifugation, the supernatant was removed and cells were resuspended and fixed with formaldehyde 3.7\% in PBS for $15 \mathrm{~min}$ at room temperature. Cellular suspensions were centrifuged, fixator was removed, cells were resuspended on PBS and stored at $4{ }^{\circ} \mathrm{C}$ on darkness between $12 \mathrm{~h}$ or $24 \mathrm{~h}$ until evaluation. PpIX emission measurement was made by flow cytometry (Cytomics FC500, Beckman Coulter, Corston, UK), with an excitation line of $620 \mathrm{~nm}$ and emission of $670 \mathrm{~nm}$. Data were referred to the control (basal synthesis of PpIX). Each experiment was repeated three times.

\subsection{Cell Cycle Evaluation}

Cells distribution throughout the cell cycle phases was studied by flow cytometry. Culture flasks at $24-48 \mathrm{~h}$ after phototreatment $\left(0.3 \mathrm{mM}\right.$ of MAL for $5 \mathrm{~h}$ and a light dose of $\left.2.25 \mathrm{~J} / \mathrm{cm}^{2}\right)$ medium containing floating cells were separated and attached cells were trypsinized. Floating and attached cells were collected together and centrifuged at $2000 \mathrm{rpm}$ for $10 \mathrm{~min}$. Afterwards, medium was discharged and cells were fixed in cold $70 \%(v / v)$ ethanol $\left(-20^{\circ} \mathrm{C}\right)$ for $5 \mathrm{~min}$. After RNase A digestion $\left(0.1 \mathrm{mg}\right.$ of RNase A at $37^{\circ} \mathrm{C}$ for $30 \mathrm{~min}$ ), the cells were stained with $50 \mathrm{mg} \mathrm{mL}$ PI for $30 \mathrm{~min}$ before analysis with flow cytometer (Becton-Dickinson FAC Scalibur, San Jose, CA, USA). PpIX has been already photodegraded and therefore, it does not interfere with PI fluorescence in cell cycle analysis (Supplementary Figure S5c). Measurements were taken on a Beckman Coulter EPICS XL-MCL flow cytometer with an argon laser line at $488 \mathrm{~nm}$ complemented with appropriate filters. Cell cycle experiments were repeated at least three times. 


\subsection{Immunostaining}

Cells grown on the coverslips were fixed in cold methanol $\left(-20{ }^{\circ} \mathrm{C}\right)$ for $7 \mathrm{~min}$, washed with distilled water three times and stored with $0.1 \%$ Triton X-100-PBS until processing. For immunostaining, cells were incubated with primary antibody for $1 \mathrm{~h}$ at $37^{\circ} \mathrm{C}$, inside a humid chamber. After washing with PBS, cells were incubated with the secondary antibody for $45 \mathrm{~min}$ at $37^{\circ} \mathrm{C}$. Coverslips were then washed with PBS and mounted with ProLong®with DAPI ( $1 \mu \mathrm{g} / \mathrm{mL})$. Images were taken with a fluorescent microscopy Olympus BX610. Mitotic index (MI) was determined after IF for $\alpha$-tubulin by counting cells in division (prophase, metaphase and anaphase-telophase) and metaphases were divided in normal and abnormal figures, depending on whether or not the spindle apparatus was altered; 700 cells were counted for MI determination. For measuring $\gamma \mathrm{H} 2 \mathrm{AX}$ positive cells, 500 cells per condition, in three independent samples.

\subsection{Western Blots}

For Western blot analysis, cells were lysed in RIPA buffer (150 mM NaCl, 1\% Triton X-100, 1\% deoxycholate, $0.1 \%$ SDS, $10 \mathrm{mM}$ Tris-HCl pH 7.2, $5 \mathrm{mM}$ EDTA), containing the appropriate concentration of Phosphatase Cocktail and Protease Inhibitor Cocktail (Sigma-Aldrich). Protein concentration was measured by the BCA Protein Assay Kit (Termo Scientific Pierce, Rockford, IL, USA). The proteins were electrophoresed and blotted on Immobilon-P PVDF membranes (Millipore Co., MA, USA). Membranes were blocked in PBS-tween $0.1 \%$ with $5 \%$ non-fat dried milk for $1 \mathrm{~h}$ at $25{ }^{\circ} \mathrm{C}$ and then incubated with the first antibody overnight at $4{ }^{\circ} \mathrm{C}$. After washing with PBS-tween $0.1 \%$, membranes were subjected to the peroxidase-conjugated secondary antibody and developed by chemiluminescence (ECL, Amersham Pharmacia Biotech, Little Chalfont, UK) employing the high definition system ChemiDocTR XRS+ (Bio-Rad Laboratories, Hercules, CA, USA). The bands corresponding to the different proteins were digitalized employing the Image Lab version 3.0.1 (Bio-Rad Laboratories). This assay was performed three times for each protein.

\subsection{Optical Microscopy}

Microscopic observations were carried out using an Olympus BX61 epifluorescence microscope equipped with filter sets for fluorescence microscopy: ultraviolet (exciting filter BP360-390), blue (exciting filter BP460-490), and green (exciting filter BP510-550). Photographs were obtained with the digital camera Olympus CCD DP70 and processed using the Adobe Photoshop CS5 extended version 12.0 software (Adobe Systems Inc., San Jose, CA, USA).

\subsection{Statistical Analysis}

Data are expressed as the mean value of at least three experiments \pm standard deviations (SD). The statistical analysis was made with the SPSS 15.0.1 software (SPSS Inc., Chicago, IL, USA). The statistical significance was determined using $t$ test and analysis of variance (ANOVA), and $p<0.05$ was considered statistically significant.

\section{Conclusions}

The present study shows that MAL-PDT in the human HeLa carcinoma cells induces accumulation of mitotic cells. Additionally, it induces the appearance of spindle abnormalities, chromosome disaggregation, and multipolar cell division generation of daughter cells with macronuclei or multinucleated. All these features are indicative of MC, which occurs probably by targeting MT. $\mathrm{MC}$ is resolved mainly by subsequent apoptosis.

Supplementary Materials: Supplementary materials can be found at http:/ / www.mdpi.com/1422-0067/20/5/ 1229/s1. Figure S1: PpIX production in HaCaT cells; Figure S2: $\gamma H 2 A . X$ and DAPI expression in cells exposed to MAL or to light red alone; Figure S3: microtubular alterations in interphase; Figure S4: Location of AURKA 
and AURKB cell cycle phases of control HeLa cells; Figure S5: justification methodology. Movie 1: control cells; Movie 2: MAL-PDT cells.

Author Contributions: A.J. conceived and designed the experiments. M.M., A.D., E.C. and S.R.L. performed the experiments. A.J., M.M., P.D.-W., wrote the manuscript. All the authors contributed in the final discussion of the paper.

Funding: This research was funded by Spanish grants from Instituto de Salud Carlos III MINECO and Feder Funds (FIS PI15/00974 and PI18/00708).

Acknowledgments: We wish to acknowledge Sara Caballero and Alicia Zamarrón from the Department of Biology, Faculty of sciences, Universidad Autónoma (Madrid, Spain) for helping us in the methodology of the work. We also thank Carmen Moreno-Ortiz from Flow Cytometry and Sylvia Gutiérrez-Erlandsson from confocal microscopy, Centro Nacional de Biotecnología (Madrid, Spain).

Conflicts of Interest: The authors declare no conflicts of interest. The founding sponsors had no role in the design of the study; in the collection, analyses or interpretation of data; in the writing of the manuscript; nor in the decision to publish the results.

\begin{tabular}{ll}
\multicolumn{2}{l}{ Abbreviations } \\
ALA & 5-aminolevulinic acid \\
AO & Acridine Orange \\
AURK A & Aurora kinase A \\
AURK B & Aurora kinase B \\
EB & Ethidium Bromide \\
IF & Immunofluorescence \\
MAL & Methyl-aminolevulinate \\
MC & Mitotic Catastrophe \\
MTs & Microtubules \\
Nc & Nocodazole \\
PDT & Photodynamic Therapy \\
PpIX & Protoporphyrin IX \\
PS & Photosensitizer \\
ROS & Reactive Oxygen Species \\
Tx & Taxol \\
WB & Western Blot
\end{tabular}

\section{References}

1. Megna, M.; Fabbrocini, G.; Marasca, C.; Monfrecola, G. Photodynamic Therapy and Skin Appendage Disorders: A Review. Skin Appendage Disord. 2017, 2, 166-176. [CrossRef]

2. Baskaran, R.; Lee, J.; Yang, S.G. Clinical development of photodynamic agents and therapeutic applications. Biomater. Res. 2018, 22, 25. [CrossRef] [PubMed]

3. Hodgkinson, N.; Kruger, C.A.; Abrahamse, H. Targeted photodynamic therapy as potential treatment modality for the eradication of colon cancer and colon cancer stem cells. Tumour Biol. 2017, 39, 1-17. [CrossRef] [PubMed]

4. Cohen, D.K.; Lee, P.K. Photodynamic Therapy for Non-Melanoma Skin Cancers. Cancers 2016, 8, 90. [CrossRef] [PubMed]

5. Zhao, Z.R.; Lau, R.W.H.; Ng, C.S.H. Catheter-based alternative treatment for early-stage lung cancer with a high-risk for morbidity. J. Thorac. Dis. 2018, 10, S1864-S1870. [CrossRef] [PubMed]

6. Van Straten, D.; Mashayekhi, V.; de Bruijn, H.S.; Oliveira, S.; Robinson, D.J. Oncologic Photodynamic Therapy: Basic Principles, Current Clinical Status and Future Directions. Cancers 2017, 9, 19. [CrossRef] [PubMed]

7. Abrahamse, H.; Hamblin, M.R. New photosensitizers for photodynamic therapy. Biochem. J. 2016, 473, 347-364. [CrossRef] [PubMed]

8. Fonda-Pascual, P.; Moreno-Arrones, O.M.; Alegre-Sanchez, A.; Saceda-Corralo, D.; Buendia-Castaño, D.; Pindado-Ortega, C.; Fernandez-Gonzalez, P.; Velazquez-Kennedy, K.; Calvo-Sánchez, M.I.; Harto-Castaño, A.; 
et al. In situ production of ROS in the skin by photodynamic therapy as a powerful tool in clinical dermatology. Methods 2016, 109, 190-202. [CrossRef] [PubMed]

9. Ash, C.; Dubec, M.; Donne, K.; Bashford, T. Effect of wavelength and beam width on penetration in light-tissue interaction using computational methods. Lasers Med. Sci. 2017, 32, 1909-1918. [CrossRef] [PubMed]

10. Yu, X.; Zheng, H.; Chan, M.T.V.; Wu, W.K.K. Immune consequences induced by photodynamic therapy in non-melanoma skin cancers: A review. Environ. Sci. Pollut. Res. Int. 2018, 25, 20569-20574. [CrossRef] [PubMed]

11. Zhang, J.; Jiang, C.; Longo, J.P.F.; Azevedo, R.B.; Zhang, H.; Muehlmann, L.A. An updated overview on the development of new photosensitizers for anticancer photodynamic therapy. Acta Pharm. Sin. B. 2018, 8, 137-146. [CrossRef] [PubMed]

12. Naidoo, C.; Kruger, C.A.; Abrahamse, H. Photodynamic Therapy for Metastatic Melanoma Treatment: A Review. Technol. Cancer Res. Treat. 2018, 17, 1-15. [CrossRef] [PubMed]

13. Robertson, C.A.; Hawkins, D.; Abrahamse, H. Photodynamic therapy (PDT): A short review on cellular mechanisms and cancer research applications for PDT. J. Photochem. Photobiol. B 2009, 96, 1-8. [CrossRef] [PubMed]

14. Soares, A.R.; Neves, M.G.; Tomé, A.C.; Iglesias-de la Cruz, M.C.; Zamarrón, A.; Carrasco, E.; González, S.; Cavaleiro, J.A.S.; Torres, T.; Guldi, D.M.; et al. Glycophthalocyanines as photosensitizers for triggering mitotic catastrophe and apoptosis in cancer cells. Chem. Res. Toxicol. 2012, 25, 940-951. [CrossRef] [PubMed]

15. Mroz, P.; Yaroslavsky, A.; Kharkwal, G.B.; Hamblin, M.R. Cell death pathways in photodynamic therapy of cancer. Cancers 2011, 3, 2516-2539. [CrossRef] [PubMed]

16. Berghe, T.V.; Linkermann, A.; Jouan-Lanhouet, S.; Walczak, H.; Vandenabeele, P. Regulated necrosis: The expanding network of nonapoptotic cell death pathways. Nat. Rev. Mol. Cell Biol. 2014, 15, 135-147. [CrossRef] [PubMed]

17. Abrahamse, H.; Tynga, I.S.M. Photodynamic Therapy, a Potential Therapy for Improve Cancer Management. In Breast Cancer and Surgery, 1st ed.; Bulut, N., Ed.; IntechOpen: London, UK, 2018; Chapter 10; pp. 181-198. [CrossRef]

18. Lin, S.; Yang, L.; Shi, H.; Du, W.; Qi, Y.; Qiu, C.; Liang, X.; Shi, W.; Liu, J. Endoplasmic reticulum-targeting photosensitizer Hypericin confers chemo-sensitization towards oxaliplatin through inducing pro-death autophagy. Int. J. Biochem. Cell Biol. 2017, 87, 54-68. [CrossRef] [PubMed]

19. Kessel, D. Apoptosis, Paraptosis and Autophagy: Death and Survival Pathways Associated with Photodynamic Therapy. Photochem. Photobiol. 2018, 95, 119-125. [CrossRef] [PubMed]

20. Ricci, M.S.; Zong, W.X. Chemotherapeutic approaches for targeting cell death pathways. Oncologist 2006, 11, 342-357. [CrossRef] [PubMed]

21. Galluzzi, L.; Vitale, I.; Aaronson, S.A.; Abrams, J.M.; Adam, D.; Agostinis, P.; Alnemri, E.S.; Altucci, L.; Amelio, I.; Andrews, D.W.; et al. Molecular mechanisms of cell death: Recommendations of the Nomenclature Committee on Cell Death 2018. Cell Death Differ. 2018, 25, 486-541. [CrossRef] [PubMed]

22. Juarranz, A.; Espada, J.; Stockert, J.C.; Villanueva, A.; Polo, S.; Domínguez, V.; Cañete, M. Photodamage Induced by Zinc (II)-phthalocyanine to Microtubules, Actin, $\alpha$-Actinin and Keratin of HeLa Cells. Photochem. Photobiol. 2001, 73, 283-289. [CrossRef]

23. Cenklová, V. Photodynamic therapy with TMPyP-Porphyrine induces mitotic catastrophe and microtubule disorganization in HeLa and G361 cells, a comprehensive view of the action of the photosensitizer. J. Photochem. Photobiol. B 2017, 173, 522-537. [CrossRef] [PubMed]

24. Foerster, F.; Braig, S.; Moser, C.; Kubisch, R.; Busse, J.; Wagner, E.; Schmoeckel, E.; Mayr, D.; Schmitt, S.; Huettel, S.; et al. Targeting the actin cytoskeleton: Selective antitumor action via trapping PKCE. Cell Death Dis. 2014, 5, e1398. [CrossRef] [PubMed]

25. Jordan, M.A.; Toso, R.J.; Thrower, D.; Wilson, L. Mechanism of mitotic block and inhibition of cell proliferation by taxol at low concentraions. PNAS 1993, 90, 9552-9556. [CrossRef] [PubMed]

26. Wei, J.H.; Seemann, J. Nakiterpiosin targets tubulin and triggers mitotic catastrophe in human cancer cells. Mol. Cancer Ther. 2010, 9, 3375-3385. [CrossRef] [PubMed]

27. Rello-Varona, S.; Stockert, J.C.; Cañete, M.; Acedo, P.; Villanueva, Á. Mitotic catastrophe induced in HeLa cells by photodynamic treatment with Zn (II)-phthalocyanine. Int. J. Oncol. 2008, 32, 1189-1196. [CrossRef] [PubMed] 
28. Rello, S.; Stockert, J.C.; Moreno, V.; Gamez, A.; Pacheco, M.; Juarranz, A.; Cañete, M.; Villanueva, A. Morphological criteria to distinguish cell death induced by apoptotic and necrotic treatments. Apoptosis 2005, 10, 201-208. [CrossRef] [PubMed]

29. Kavallaris, M. Microtubules and resistance to tubulin-binding agents. Nat. Rev. Cancer 2010, 10, $194-204$. [CrossRef] [PubMed]

30. Jordan, M.A.; Wilson, L. Microtubules as a target for anticancer drugs. Nat. Rev. Cancer 2004, 4, $253-265$. [CrossRef] [PubMed]

31. Cicenas, J. The Aurora kinase inhibitors in cancer research and therapy. J. Cancer Res. Clin. Oncol. 2016, 142, 1995-2012. [CrossRef] [PubMed]

32. Sabbaghi, M.; Gil-Gómez, G.; Guardia, C.; Servitja, S.; Arpi, O.; García-Alonso, S.; Menendez, S.; Arumi-Uria, M.; Serrano, L.; Salido, M.; et al. Defective cyclin B1 induction in trastuzumab-emtansine (T-DM1) acquired resistance in HER2-positive breast cancer. Clin. Cancer Res. 2017, 23, 7006-7019. [CrossRef] [PubMed]

33. Castedo, M.; Perfettini, J.L.; Roumier, T.; Andreau, K.; Medema, R.; Kroemer, G. Cell death by mitotic catastrophe: A molecular definition. Oncogene 2004, 23, 2825-2837. [CrossRef] [PubMed]

34. Wen, X.; Li, Y.; Hamblin, M.R. Photodynamic therapy in dermatology beyond non-melanoma cancer: An update. Photodiagnosis Photodyn. Ther. 2017, 19, 140-152. [CrossRef] [PubMed]

35. Tyrrell, J.; Paterson, C.; Curnow, A. Regression Analysis of Protoporphyrin IX Measurements Obtained During Dermatological Photodynamic Therapy. Cancers 2019, 11, 72. [CrossRef] [PubMed]

36. Griffin, L.L.; Lear, J.T. Photodynamic Therapy and Non-Melanoma Skin Cancer. Cancers 2016, 8, 98. [CrossRef] [PubMed]

37. Aguilar-Bernier, M.; Rodríguez-Barón, D.; Ruiz, F.R.; Segura-Palacios, J.M.; Martín, M.T. Long-term efficacy of photodynamic therapy with methyl aminolevulinate in treating Bowen's disease in clinical practice: A retrospective cohort study (2006-2017). Photodermatol. Photoimmunol. Photomed. 2019. [CrossRef] [PubMed]

38. Ji, Z.; Yang, G.; Vasovic, V.; Cunderlikova, B.; Suo, Z.; Nesland, J.M.; Peng, Q. Subcellular localization pattern of protoporphyrin IX is an important determinant for its photodynamic efficiency of human carcinoma and normal cell lines. J. Photochem. Photobiol. B 2006, 84, 213-220. [CrossRef] [PubMed]

39. Chen, R.; Huang, Z.; Chen, G.; Li, Y.; Chen, X.; Chen, J.; Zeng, H. Kinetics and subcellular localization of 5-ALA-induced PpIX in DHL cells via two-photon excitation fluorescence microscopy. Int. J. Oncol. 2008, 32, 861-867. [CrossRef] [PubMed]

40. Kim, C.H.; Chung, C.W.; Choi, K.H.; Yoo, J.J.; Kim, D.H.; Jeong, Y.I.; Kang, D.H. Effect of 5-aminolevulinic acid-based photodynamic therapy via reactive oxygen species in human cholangiocarcinoma cells. Int. J. Nanomed. 2011, 6, 1357-1363. [CrossRef]

41. Erenpreisa, J.; Cragg, M.S. Mitotic death: A mechanism of survival. Cancer Cell Int. 2001, 1, 1. [CrossRef] [PubMed]

42. Blagosklonny, M.V. Mitotic arrest and cell fate: Why and how mitotic inhibition of transcription drives mutually exclusive events. Cell Cycle 2007, 6, 70-74. [CrossRef] [PubMed]

43. Forer, A.; Sheykhani, R.; Berns, M.W. Anaphase Chromosomes in Crane-Fly Spermatocytes Treated with Taxol (Paclitaxel) Accelerate When Their Kinetochore Microtubules Are Cut: Evidence for Spindle Matrix Involvement With Spindle Forces. Front. Cell Dev. Biol. 2018, 6, 77. [CrossRef] [PubMed]

44. Giovinazzi, S.; Bellapu, D.; Morozov, V.M.; Ishov, A.M. Targeting mitotic exit with hyperthermia or APC/C inhibition to increase paclitaxel efficacy. Cell Cycle 2013, 12, 2598-2607. [CrossRef] [PubMed]

45. Chumduri, C.; Gillissen, B.; Richter, A.; Richter, A.; Milojkovic, A.; Overkamp, T.; Müller, A.; Pott, C.; Daniel, P.T. Apoptosis resistance, mitotic catastrophe, and loss of ploidy control in Burkitt lymphoma. J. Mol. Med. 2015, 93, 559-572. [CrossRef] [PubMed]

46. Nikonova, A.S.; Astsaturov, I.; Serebriiskii, I.G.; Dunbrack, R.L.; Golemis, E.A. Aurora A kinase (AURKA) in normal and pathological cell division. Cell. Mol. Life Sci. 2013, 70, 661-687. [CrossRef] [PubMed]

47. Carmena, M.; Earnshaw, W.C. The cellular geography of aurora kinases. Nat. Rev. Mol. Cell Biol. 2003, 4, 842-854. [CrossRef] [PubMed]

48. Pannu, V.; Rida, P.C.G.; Ogden, A.; Clewley, R.; Cheng, A.; Karna, P.; Lopus, M.; Mishra, R.C.; Zhou, J.; Aneja, R. Induction of robust de novo centrosome amplification, high-grade spindle multipolarity and metaphase catastrophe: A novel chemotherapeutic approach. Cell Death Dis. 2012, 3, e346. [CrossRef] [PubMed] 
49. Choi, H.J.; Fukui, M.; Zhu, B.T. Role of cyclin B1/Cdc2 up-regulation in the development of mitotic prometaphase arrest in human breast cancer cells treated with nocodazole. PLoS ONE 2011, 6, e24312. [CrossRef] [PubMed]

50. Georgoulis, A.; Vorgias, C.; Chrousos, G.; Rogakou, E. Genome instability and $\gamma$ H2AX. Int. J. Mol. Sci. 2017, 18, 1979. [CrossRef] [PubMed]

51. Ho, L.; Read, S.H.; Dorstyn, L.; Lambrusco, L.; Kumar, S. Caspase-2 is required for cell death induced by cytoskeletal disruption. Oncogene 2008, 27, 3393-3404. [CrossRef] [PubMed]

52. Castedo, M.; Perfettini, J.L.; Roumier, T.; Valent, A.; Raslova, H.; Yakushijin, K.; Horne, D.; Feunteun, J.; Lenoir, G.; Medema, R.; et al. Mitotic catastrophe constitutes a special case of apoptosis whose suppression entails aneuploidy. Oncogene 2004, 23, 4362-4379. [CrossRef] [PubMed]

53. Kosmider, B.; Zyner, E.; Osiecka, R.; Ochocki, J. Induction of apoptosis and necrosis in A549 cells by the cis-Pt (II) complex of 3-aminoflavone in comparison with cis-DDP. Mutat. Res. 2004, 563, 61-70. [CrossRef] [PubMed]

(C) 2019 by the authors. Licensee MDPI, Basel, Switzerland. This article is an open access article distributed under the terms and conditions of the Creative Commons Attribution (CC BY) license (http://creativecommons.org/licenses/by/4.0/). 